\title{
EDITORIAL
}

\section{The Proposed EU Interest and Royalties Directive}

\author{
J. David B. Oliver, PricewaterhouseCoopers, London
}

It is now almost 18 months since ECOFIN Ministers agreed to pursue a package of measures for the EU comprising a code of conduct for business taxation, a directive on the taxation of savings, and a directive on the taxation of cross-border interest and royalty payments between associated companies. ${ }^{1}$ There has been much debate on the desirability of the savings directive and speculation on the content of the code of conduct, but what about the interest and royalties directive? Does this represent a step forward, either on its own or as part of the package? Let us consider its merits on a stand-alone basis and thus avoid being drawn into a debate on the merits or otherwise of the other measures in the package. ${ }^{2}$

\section{The starting point}

The starting point is that withholding taxes on interest and royalties exist in most of the domestic regimes of the EU. Domestic rules however are modified by the bilateral treaty network. The bilateral treaties will in many cases already eliminate or significantly reduce the level of withholding tax. ${ }^{3}$ However there may be considerable variances in the manner by which this result is achieved. There may be relief at source or there may be a refund system, or a combination of the two. The procedures for invoking the treaty provisions may vary.

\section{The scope of the directive}

The siting of debt and of patents, trademarks etc., gives rise to business decisions of key importance in international tax planning. It is one of the most important areas of tax planning for many businesses. Where the debt or patents etc. are owing to or held by third parties then prima facie there is an arm's-length transaction. Where the transaction is within a group of companies on the other hand questions may arise as to whether it conforms to arm's-length principles and whether it has some tax-avoidance motive.

The Directive thus addresses two very sensitive areas, namely the general field of interest and royalties and in particular the matter of interest and royalties paid between companies which are associated. Thus by definition the Directive will not apply in a complete third-party situation.

The scope of the Directive will therefore by its very nature lead to calls for anti-abuse or anti-avoidance measures to be included in the Directive. Such measures may then lead to difficulties in applying the Directive and may thus to some extent frustrate it in fulfilling its objective.

\section{A. Definition of interest and royalties}

The proposed definition of interest follows the OECD Model definition (with the natural omission of government securities). Likewise the definition of royalty follows the OECD Model definition but with the addition of software: this amendment therefore deals with the kind of issue concerning software payments which is addressed in the proposed revision of the Commentary on Art. 12 of the OECD Model.

The definition is helpfully extended so that if there is a double taxation convention in force between the two Member States then the definition in that Convention, if wider, is adopted for the purposes of the directive. Conversely if there is no Convention then the domestic law definition is followed, if wider. Therefore a state adopting a broad domestic law definition cannot escape the operation of the directive on the broader definition - but what if the state called the payments something else (e.g. technical fees)?

\section{B. Associated companies}

The definition of 'company of a Member State' states that it is 'any company formed in accordance with the

\section{Notes}

See Mario Monti, 'The Climate is Changing', EC Tax Review 1998/1 at p. 2.

Interest and Royalties Directive: A Step Forward? formed the subject of an interesting debate at a CFE Forum in Brussels on 21 April 1999.

Tables in the 4 March 1998 proposal for a Council Directive set out the position in September 1997 under the domestic regimes and under the various treaty arrangements. 
law of a Member State ...'. One compares this approach with the more prescriptive approach of the Mergers Directive and the Parent/Subsidiary Directive which list the qualifying companies in an Annex. However, whatever 'company' itself may mean it must be a 'company' which is subject to one of the Member State taxes as listed in the directive. ${ }^{4}$ (Art. 3(1)(c)(iii).)

The association is based on direct or indirect 'ownership' of 25 per cent in the capital of the company. The Directive however does not use 'ownership', it uses the expression '... has directly or indirectly a minimum holding of $25 \%$...'. This follows the Parent/Subsidiary Directive but is it quite clear what is meant by '.. has a holding ...'? Likewise, what is meant by 'capital'? 'Capital' is used in the Parent/Subsidiary Directive and its meaning is equally unclear there. Capital, in commercial usage, may include equity capital, share capital carrying a right to fixed dividends, loan capital and indeed other borrowings, whether or not convertible into equity or other share capital, depending on the context. Can we not learn some lessons from the Parent/Subsidiary Directive?

\section{Permanent establishments}

Payments by or to a permanent establishment are included within the exemption. This is one of the most welcome features of the Directive. Difficulties arise under double taxation conventions in triangular cases and, in particular, where the permanent establishment is exempt from tax in the country of residence but the treaty between the source state and the residence state has a 'subject to tax' clause so that the treaty does not apply. The Directive cuts through these difficulties, as indeed does the EC Arbitration Convention which likewise extends to permanent establishments. The Directive therefore represents an advance on the bilateral treaty position in this respect.

\section{Interest as a distribution of profit}

The Directive provides that interest recharacterized as a distribution of profits (and therefore outside the interest and royalties directive) is to be subject to the Parent/Subsidiary Directive. This appears to be (but see below) a very helpful provision in relieving the double taxation which would otherwise occur, by exempting the receipt or giving relief for underlying tax.

It is possible that such interest may fall within the Parent/Subsidiary Directive anyway, as 'a distribution of profits' for the purposes of that Directive, but that expression is not defined in that Directive. Even if it did fall within the Directive it would only apply to a payment by the company to its shareholder. By Art. 4 of the interest and royalties Directive it might be argued that it can apply not only in that situation but also to payments between sister companies ('between companies to which the present Directive applies'). Therefore, quaere, it could also apply to payments down the chain, i.e. by a parent to its subsidiary.

The commentary on Art. 4 in the Commission's Explanatory Memorandum suggests, however, that this is not the case. The Parent/Subsidiary Directive, it states, applies '... provided all the other requirements of that Directive are met ...' On this basis a payment by a shareholder to the company and a payment between sister companies (in the absence of any shareholding/voting power link between those companies), would not qualify. If this is right then the proposed Directive has missed the opportunity to remedy double taxation.

\section{Anti-avoidance measures}

One must expect (see the remarks under 2. above) that there will be anti-avoidance provisions (compare the Merger Directive (Art. 11) and the Parent/Subsidiary Directive (Art. (2)). Are these measures however too numerous and do they overlap, potentially frustrating the operation of the Directive? The measures can be classified as follows: ${ }^{5}$

(i) A company of a Member State means '... any company formed in accordance with the law of a Member State ... and whose activities present an effective and continuous link with the economy of that Member State; .... So if a company is formed in one Member State but is resident and conducts all its business in another Member State, does it qualify as a company of a Member State? (Art. 3(1)(a)(i).) What constitutes 'an effective and continuous link'?

(ii) Treaty residence in a third country outside the community may disqualify a company. (Art. 3 (1) (a) (ii).)

(iii) The recipient must be the beneficial owner. This requirement follows the OECD Model but helpfully the Directive seeks to explain what is meant by beneficial owner. Would it not, however, have been enough to stop at a reference to an agent or nominee rather than also including a trustee, who may or may not have an interest himself in the income? (Art. 3(1)(c)); compare the Commentary on Art. 11 of the OECD Model at para. 8: '... the limitation of tax in the State of

\section{Notes}

4 It is possible that one Member State may regard the entity as a company and another Member State regards it as transparent: in such a case the position would seem to be governed by the classification in the state of formation, provided that the company is subject to one of the Member State taxes listed.

5 In addition certain types of income (e.g. interest on profit participating loans) are excluded from the directive. 
source is not available when an intermediary, such as an agent or nominee, is interposed between the beneficiary and the payer, unless the beneficial owner is a resident of the other Contracting State'.

(iv) The benefit of the Directive may be withdrawn if the conditions for the holding of capital or voting power have not been maintained for an uninterrupted period of a minimum of two years. Compare the Parent/Subsidiary Directive which refers to 'not applying' the Directive in such circumstances: one hopes that that lesson has been learned. (Art. 3(2).)

(v) A special relationship provision. This is based on the OECD Model. (Art. 5.)

(vi) 'Appropriate measures' may be taken 'to combat fraud or abuse'. (Art. 6(1).)

(vii) A Member State may withdraw the benefit of the Directive or refuse to apply it in the case of any transaction which has as its principal objective or as one of its principal objectives tax evasion or tax avoidance. (Art. 6(2).)

(viii) Income subjected to tax at a rate lower (how much lower?) than the rate normally applicable or which benefits from a reduction in the tax base not usually available is outside the application of the Directive, at the direction of the Member State authorizing the application of the provisions to the particular payment. (Art. 7.)

Why is it necessary to have all four of the provisions in (v) - (viii) above? The Parent/Subsidiary Directive (Art. 1(2)) makes do with just the provision in (vi) while the merger directive does likewise with the provision in (vii).

\section{The application of the Directive}

The key to the success of the Directive probably lies in its application. Given the existing treaty network (see the remarks under 2. above) the wider benefit (wider that is than the reduction of rates which may already have occurred under the treaties) may be expected to be in the application of the Directive at source to payments of interest and royalties. This would imply discarding refund procedures in favour of giving relief at source at the time of payment and it also implies streamlining the requirements for proof that the benefit of the Directive may be taken.

The concern would be that anti-avoidance measures may allow a Member State to apply procedures which are no less onerous or complicated than the present procedures for treaty relief. For example a state may require proof that interest is not a distribution of profit before agreeing to apply the Directive.

If the goals of simpler procedures and a minimization of cash-flow loss through withholding taxes can be achieved then the Directive, on a stand-alone basis, will represent a step forward; but to achieve this may call for some streamlining of the anti-avoidance provisions in the present draft as already suggested by the Economic Affairs Committee of the European Parliament. It may also call for a recognition that if the payments are excessive or fall foul of one of the other tax-avoidance rules then the payment, to that extent, is being regarded as a transfer of profit. The Parent/Subsidiary Directive allows the distribution of profit by subsidiary to parent to be exempt from withholding tax. Why should not this principle be extended to both interest and royalties which fall outside the interest and royalty directive (because, for example, of the anti-avoidance rules) with the result that there is still no withholding tax. The draft directive is not dealing with the deductibility for corporation tax purposes of such payments. That is a separate matter and quite properly the Directive does not address it: it is only dealing with the withholding tax issue. On that basis there should be no need for the plethora of anti-avoidance provisions which not only may be taken to have different meanings in different Member States but may also be used to hinder or frustrate the purpose of the Directive. 